\title{
Comparative Microbial Analysis of Earthworm Casts Collected From Ikenne, Ogun State, Nigeria \\ Dedeke, G.A ${ }^{1 *}$., Omemu, $\mathbf{O}^{2}$ Aladesida, A.A ${ }^{3}$., and Museliu, $\mathrm{F}^{4}$
}

\section{Abstract}

A comparative assessment of the physicochemical parameters and microbial profile of three types of earthworm casts (Pellet, Mass and Turret) were determined. The total viable count (TVC), coliform counts, yeast and mould counts were determined using standard procedures. The $\mathrm{pH}$ ranged from 7.8 for Mass cast to 8.6 for Pellet cast. Moisture content of the casts ranged from $29.43 \%$ for pellet casts to $47.10 \%$ for turret casts. Organic matter was $1.05 \%, 0.72 \%$ and $0.63 \%$ for pellet, turret and mass casts respectively. TVC was $4.8 \times 10^{7} \mathrm{cfu} / \mathrm{g}, 6.1 \mathrm{x}$ $10^{7} \mathrm{cfu} / \mathrm{g}$ and $1.2 \times 10^{8} \mathrm{cfu} / \mathrm{g}$ for Mass, Turret and Pellet casts respectively. Pellet cast recorded the highest coliform count $\left(1.5 \times 10^{7}\right)$ while Turret cast the least $\left(7.3 \times 10^{6} \mathrm{cfu} / \mathrm{g}\right)$. Mould counts was $8.3 \times 10^{6} \mathrm{cfu} / \mathrm{g}$ for turret cast and $1.2 \times 10^{7} \mathrm{cfu} / \mathrm{g}$ for pellet and mass casts. The lowest yeasts count was $1.2 \times 10^{7} \mathrm{cfu} / \mathrm{g}$ in mass cast while the highest was $3.8 \times 10^{7} \mathrm{cfu} / \mathrm{g}$ for pellet cast. Microbial distribution in the three casts types showed that Staphylococcus aureus is common to all Cast-types. Citrobacter spp, Pseudomonas fluorescens, Penicillium chrysogenum and S. rosei were isolated from Pellet cast only. Aspergillus fumigatus, Fusarium oxisporum, Pseudomonas aeruginosa and Penicillium oxalicum were isolated from only Turret Cast while Aspergillus terreus, Fusarium compacticum, Klebsiella aerogenes and Streptococcus feacalis were isolated from Mass Cast only. The presence of Bacillus licheniformis in Pellet Cast is an advantage plus for Pellet cast usage since this bacteria contributes to nutrient cycling and displays antifungal activities.

\section{Keywords: Pellet cast, Turret cast, Mass cast, Microbial Count,}

\section{Introduction}

Casting by earthworm is an been shown by several studies to have significant impact on soil fertility. A worm casting is a biologically active mound containing several bacteria, enzymes and remnants of plant materials and animal manure that were not digested by the earthworm (Appelhof, 1982). Earthworms and their casts are useful in land improvement, reclamation and in organic waste management (Edwards and Baker 1992; Johnson 1997; Lavelle and Martin 1992; Villenave et al. 1999).

Studies have revealed that earthworms contribute significantly to soil structure and soil fertility, improve water absorption and crop yield. (Edwards and Lofty, 1977; Abbot and Parker, 1981; Owa et al., 2003; Owa et al., 2004a, 2004b). Edwards and Bates (1992) reported that earthworms increased significantly the number, growth rate and yield of plants on inoculated sites. Logsdon (1994) showed that earthworms successfully decomposed sugar factory residuals and turned them into soil nutrient that allowed reduction in the use of chemical fertilizers by $50 \%$. Earthworms have been shown to increase soil porosity and soil aeration and bring about decomposition of leaf and other litters, thereby making soil nitrates and phosphorus more available in the soil (Owa et al., 2003).
Earthworm casts significantly affect plant growth through their effects on microorganisms, aggregation of soil, and nutrient supply (Sabrina et al., 2009). Reports have shown that enzymes such as $\beta$ glucosidase, alkaline phosphatase, dehydrogenase and protease are more abundant in the castings than the surrounding soil (Aira et al, 2004). Castings has been shown to absorb water faster than soil and hold more water than equivalent amounts of soil thereby increasing moisture absorption and moisture availability to plants. Furthermore, castings are known to absorb moisture from the air and hold it for plant use. Casting also holds nutrients for plant use as a non-pollutant natural fertilizer. An important component of casting is humic acid, which provides binding sites for plant nutrients such as calcium, iron, potassium, sulfur and phosphorus and releases them on demand to the plants (Sabrina et al., 2009). Casts have been shown to have enhanced microbial and enzyme activities and micro- and macro-nutrients (Vinotha et al., 2000).

In addition, nitrogen fixing bacteria which are of earthworm gut origin had been found in the castings. This resulted in higher nitrogenase activity in earthworm castings and hence greater rates of nitrogen fixation compared to the surrounding. Several reports found that castings generally have a higher ammonium concentration than bulk soils and

1, Department of Biological Sciences, ${ }^{2}$ Department of Microbiology,University of Agriculture, Abeokuta, Nigeria. gabrieldedekson@gmail.com; ${ }^{2}$ bjomemu@yahoo.com; 32Department of Biological Sciences, Bowen University, Osun State, Nigeria. aaladesida@yahoo.com; ${ }^{4}$ Department of Biochemistry, Olabisi Onabanjo University, Ogun State, University, 
they constitute sites of high denitrification potential (Elliot et al, 1990).

Logsdon (1994) showed that microbial activity in worm castings is 10-20 times higher than the soil and initial organic material ingested by the earthworm. This observation was further confirmed by Card et al (2004). This has contributed to the enrichment of the soil because the intestine of earthworms serving as a micro-incubator provides a conducive environment, within which ingested microbes could multiply rapidly. Hence, earthworms and their enteric microbes play a major role in pedogenesis, soil aggregate formation and soil aeration (Feller et al., 2003).

Three major cast-types were observed to be produced by earthworms namely: Pellet casts (granular casts) produced by Eudrilus eugeniae, Agrotoreutus spp and Eutoreutus spp (Sims, 1971; Segun, 1976); Turret casts (funnel/finger shaped) produced by Hyperiodrilus africanus and Ephyriodrilus afroccidentalis and the Mass (moldy) casts produced by Libyodrilus violaceus (Sims, 1971; Beddard, 1981).

Though there have been studies which showed that earthworm castings encourage high proliferation of microflora but most of these past works lumped all cast-types together, hence, no established data on the relative microbial population in different earthworm cast-types. This work therefore is aimed at establishing the relative microbial population of pellet, turret and mass cast-types collected from Ikenne Campus of Olabisi Onabanjo University, Ogun State.

\section{Study area}

Cast samples were collected from two sites within the Olabisi Onabanjo University, Ikenne Campus, Ogun State. Ikenne is located in South-West geo-political region of Nigeria on latitude $6^{0} 52^{\prime} \mathrm{N}$ and longitude $3^{0} 43^{\prime} \mathrm{E}$ in the rainforest zone with a mean annual rainfall of $1100 \mathrm{~mm}$. The major soil type is sandy-loam (top soil) to sandy-clay (subsoil) and the major food crops include maize, cassava, yam, rice, water melon, pineapple, cocoyam, cowpea and vegetables while the major cash crops include cocoa, rubber and cashew, oil palm tree, kolanut and timber.

\section{Materials and Methods \\ Cast collection:}

Turret casts were collected from under hedgerows within the University Campus, while the Mass and Pellet Cast were collected from more open lands located few paces away from the hedgerows. The different cast samples were collected into pre-labeled polythene bags and transferred to the soil laboratory for analysis.

\section{Physicochemical Analysis of Casts}

The $\mathrm{pH}$ of the casts was measured using Mettler digital $\mathrm{pH}$ meter with probe. The moisture content of casts was determined by the conventional method of finding the difference of fresh casts versus oven dried casts. The Organic Carbon and Organic Matter were determined by the Walkey and Black method (1934). available Phosphorus in the cast was analysed using the Bray 2 method (Bray and Kurtz, 1945). The phenoldisulphonic acid colorimetric method was used to determine the $\%$ Nitrate of the Castings. The total Nitrogen was determined using the Kjeldahl method (Bremner, 1960);

\section{Microbial Cultivation and Enumeration.}

Ten-fold dilutions of each of the samples were made using peptone water. Appropriate dilutions were made and $0.1 \mathrm{ml}$ of the diluted samples were pour plated in triplicate plates on Plate Count Agar (PCA) for viable count, Eosin Methylene Blue (EMB) for Escherichia coli count, Mannitol Salt Agar (MSA) for Staphylococcal count and Brilliant Green Bile Broth (BGBB) for coliform test. Sabourand Dextrose Agar with Chloramphenicol $(250 \mathrm{mg} / 100 \mathrm{ml})$ was used for fungi, while for yeast count the medium was adjusted to $\mathrm{pH} 3.5$ with tartaric acid. All plates were incubated for 48 hours at $30^{\circ} \mathrm{C}$ except for Sabourand Dextrose Agar that were incubated at $25^{\circ} \mathrm{C}$ for 6 days. Pure cultures of each isolate were obtained by streaking the specific colonies on suitable media and incubated appropriately, these were maintained in an agar slants in McCartney bottles.

\section{Identification of microbial isolates}

The identification of the bacteria colonies was based on classification schemes proposed by Harrigan and McCance (1976), Buchanan and Gibbons (1974) and Collins and Lyne, (1984). The identification was based essentially on morphology and biochemical reactions. Fungi genus were determined through morphological criteria using identification keys such as the description of mycelia and of asexual reproduction forms (Domsch et al., 1980).

\section{Data Analysis:}

The results were subjected to statistical analysis, these include Descriptive statistics, 
Analysis of Variance (ANOVA), Duncan Multiple Range test, Bivariate Pearson Correlation using the Statistical Package for the Social Science (SPSS) version 11.0 was used for these analysis.

\section{Results}

Table 1 presents the physicochemical parameters of different earthworm casts examined. The $\mathrm{pH}$ ranged from 7.8 for Mass cast to 8.6 for Pellet cast. The highest moisture content observed was $47.10 \%$ for Turret cast, followed by $45.60 \%$ for Mass cast and $29 \%$ for Pellet cast.

The Statistical analysis as confirmed by the Duncan multiple range test (Table 3) showed that there were significant differences between the means of all the physicochemical parameters studied. With the exception of the $\%$ Moisture content, the mean values of all other parameters were significantly $(\mathrm{p}<0.05)$ higher for Pellet casts as compared to Mass and Turret casts.

The mean microbial counts in the different cast-types presented in Table 2 showed Total Viable Count (TVC) of $4.8 \times 10^{7} \mathrm{cfu} / \mathrm{g}, 6.1 \mathrm{x}$ $10^{7} \mathrm{cfu} / \mathrm{g}$ and $1.2 \times 10^{8} \mathrm{cfu} / \mathrm{g}$ for Mass, Turret and Pellet casts respectively. Coliform count ranged from $7.3 \times 10^{6} \mathrm{cfu} / \mathrm{g}$ for Turret cast to $1.5 \times 10^{7} \mathrm{cfu} / \mathrm{g}$ for Pellet cast. Mould counts was $8.3 \times 10^{6}$ for turret cast and $1.2 \times 10^{7} \mathrm{cfu} / \mathrm{g}$ for pellet and mass casts. The lowest yeasts count was $1.2 \times 10^{7} \mathrm{cfu} / \mathrm{g}$ in mass cast while the highest was $3.8 \times 10^{7} \mathrm{cfu} / \mathrm{g}$ for pellet cast.

Generally significantly $(\mathrm{p}<0.05)$ higher microbial count was observed for Pellet cast as compared to the other cast-types examined. Statistical analysis also showed that the differences between the mean microbial counts were significant (Table 4).

The distribution of the microbial isolates in the different earthworm cast-types is presented in Table 5. Fourteen (14) bacterial species isolated from the three casts were Aerobacter aerogenes, Bacillus cereus, Bacillus licheniformis, Bacillus cereus, Citrobacter spp, Escherichia coli, Klebsiella aerogenes, Proteus vulgaris, Proteus morgani, Pseudomonas fragii, Pseudomonas aeruginosa, Pseudomonas fluorescens, Staphylococcus aureus, Streptococcus faecalis and Serratia marcescens. Out of these 15 bacterial species, Staphylococcus aureus was obtained from the three casts, Citrobacter spp and Pseudomonas fluorescens were isolated only from Pellet cast; Streptococcus faecalis and Klebsiella aerogenes were isolated only from Mass casts while Pseudomonas aeruginosa was isolated only from Turret casts. Bacillus cereus, Pseudomonas fragii and Proteus vulgaris were isolated only from pellet and turret casts and not from any of the mass cast examined.

Seven mould species were isolated from the three casts and they are Aspergillus niger, Aspergillus fumigatus, Aspergillus terreus, Fusarium compacticum, Fusarium oxisporium, Penicillium chrysogenum and Penicillium oxilicum. Only Aspergillus niger and Penicillium chrysogenum were isolated from pellet casts; $A$. fumigates, $F$. oxisporium and $P$. oxilicum were isolated from Turret casts while $A$. niger, A. terreus and $F$. compacticum were obtained from mass casts.

Four yeasts species isolated were Candida spp, Saccharomyces rosei, $S$. cerevisiae and $S$. bayanus. Out of the four yeasts species, only $S$. cerevisiae was isolated from mass casts. $S$. cerevisiae was not isolated from turret casts and $S$. rosei was not isolated from pellet cast.

\section{Discussion}

The low moisture content of Pellet Cast compared to Turret Cast and Mass Cast suggests that the water holding capacity of turret and mass casts is much higher than Pellet cast. This low water holding capacity of pellet cast may have been due to its tiny granule-like aggregates which may make it susceptible to quicker water loss than the other cast-types. The $\mathrm{pH}$ of all cast samples fall within the range required for favourable growth of soil bacteria and fungi.

Result of this study showed the presence of several bacterial and fungal species in the different earthworm cast examined. This agrees with the findings of several authors who had reported the occurrence of several species of bacteria and fungi in earthworm casts (Alauzet, et al., 2001; Prakash, et al., 2008; Jayakumar, et al., 2009). Microorganisms generally flourish in earthworm casts (Domsch and Banse 1972). Card et al., 2004 stated that earthworm casts contain many more microbes than its surrounding soil because the intestines of earthworms inoculate the casts with microbes.

The presence of the fungi Aspergillus, Penicillium and Fusarium in the earthworms casts is not surprising as the genera Aspergillus and Penicillium are frequently found in soils (Torres et al., 1999; Alauzet, et al., 2001). 
Tiunov and Scheu (2000) reported that the biomass of fungi is higher in Lumbricus terrestris casts than in the surrounding soil. It has also been suggested that the fungi in the casts constitute a nutrient pool for earthworms (Edwards and Fletcher 1988; ).

The presence of Fusarium oxisporum, a plant pathogen in turret cast and Klebsiella aerogenes and Streptococcus feacalis in mass cast might have been due to the ingestion of the bacteria species and the spores of this fungus by the earthworm species associated with them. Previous work in literature had earlier suggested that earthworms may ingest the spores of this microorganisms and deposits it along with their casts (Edwards and Lofty, 1977; Alauzet, et al., 2001) The presence of Bacillus licheniformis in Pellet Cast is an added advantage to this cast since these bacteria contribute to nutrient cycling and displays antifungal activities.

Furthermore, the higher $\mathrm{pH}$, organic matter, organic carbon, $\%$ Nitrite, $\%$ Nitrate, \% Nitrogen and \% Phosphorus are probable the contributive factors leading to the higher Total Viable Count (TVC) observed in Pellet cast as confirmed by the Bivariate Pearson Correlation and this may have offset the negative impact of its low moisture content. This is in agreement with Atlas (1997) who revealed that these energy and electron sources (the organic and inorganic constituents of the casts) are required for microbial proliferation and vice versa.

The importance of these microbial population in earthworm casts cannot be overemphasized, their presence and bioactivities in the cast in larger amount than

\section{References}

Abbot, I and Parker, C. A (1981). Interactions between earthworm and their soil environment. SoilBiology and Biochemistry 13, 191-197

Aira, M., Monroy, F. and Domm, J. (2005). Ageing effects on Nitrogen Dynamics and enzyme activities in cast of Apporectodea caliginosa (Lumbricidae). Pedobiologia 49, 467-473.

Alauzet, N., Roussos, S., Garreau, H. and Vert, M. (2001). Microflora Dynamics in Earthworms Casts in an Artificial Soil (Biosynthesol) Containing Lactic Acid Oligomers. Brazilian Archives of Biology and Technology 44(2), $113-119$.

Appelhof, M. (1982). Worms eat my garbage. Flower Press US the surrounding soil resulted in higher organic matter, carbon content, phosphate, nitrate and nitrogen content than their surrounding soil. This makes earthworm casts suitable media for raising seedling in horticultural practices and the boost of nutrient in the cast will produce better seedling performance. Furthermore, the cast types serve as reservoir from which microbes could be transported and inoculated to new or reclaimed soil as reported by Edwards and Lofty (1977).

In conclusion, this study has shown that there is significant difference between the nutrient content, viable microbial count (load), Coliform Count, Fungal Count and Yeast Count of Pellet, Turret and Mass Casts. There is a significant and positive relationship between the microbial loads, organic matter and inorganic constituents of Pellet, Turret and Mass Casts with Pellet Cast containing higher amount of all these parameters hence will contribute more nutrient to enhance soil fertility.

However, this notwithstanding, all the casttypes could be said to play a synergistic role in enhancing soil fertility with pellet cast serving as a quick release nutrient capsules for early germination of crops before the onset of the rainy season whereas turret and mass casts would serve as a long time release capsule of nutrients during the later periods of the rainy season. It is therefore advisable for farmers and horticulturist in this area to encourage the presence of different species of earthworms, the turret casters, mass casters and pellet casters in the soil.

Atlas, R. M. (1997). Mucus Production and Microbial activity in the gut of two species of Amythas (Megascolecidae) from cold and warm tropical climates. Soil Biol. Biochem. 24, 1507-1510

Beddard, F. (1981). On the structure of two genera of earthworms belonging to the Eudrilidae and some remarks on Nemertodrilus. Quat. J. Microscop. Sci. 32, 235-278

Bray, R. H and Kurtz, L. T. (1945). Determination of total organic and available form of phosphorus in soil. Soil Soc. 59, 39-45

Bremner, J. M. (1960). Determination of nitrogen in soil by the Kjeldahl method. J.Agric. Sci. $\quad \mathbf{5 5}, 11-31$. 
Card, A. B., Anderson, J. V. and Davis, J. G. (2004). Vermicomposting Horse Manure. Colorado State University Cooperative Extension no. www.ext.colostate.edu/pubs/livestk/

01224.html. 1-224.

Domsch, K. H.; Gams, W. and Anderson, T. H. (1980), Compendium of soil fungi, Academic Press, H. B. Jovanovich Publ., London.

Domsch, K. H., Banse, H. J. (1972). Mykologische Untersuchungen an Regenwurmexkremen-ten. Soil Biology and Biochemistry 4, 31-38.

Edwards, C. A and Bates, J. E (1992). The use of earthworms in environmental management. Soil Biologyand Biochemistry 14(12), 1683- 1689

Edwards, C. A. and Lofty, T. R. (1977). Biology of earthworms, $2^{\text {nd }}$ Edition. Chapman and Hall, London p. 27

Edwards, C. A., Fletcher, K. E. (1988). Interactions between earthworms and microorganisms in organic-matter breakdown. In: Edwards, C. A., Stinner, B. R., Stinner, D., Rabatin, S. (eds.). Biological Interactions in Soil. Elsevier, New York, pp. 235-247.

Edwards, C. A. and Baker, J.E. (1992). The use of earthworms in environmental management.Soil Biol. Biochem. 24, 16831689.

Elliot, P. W., Knight, D. and Anderson, J. M. (1990). Denitrification in earthworm casts and soil from pasture under different fertilizer and drainage regimes. Soil Biology and Biochemistry. 22(5), 601-605.

Feller, C., Brown, G. G., Blanchart, E., Pierre, D., and Chernyanskii, S. S. (2003). Charles

Darwin, Earthworms and the Natural Sciences: Various Lessons from Past to Future. Agriculture, Ecosystems and Environment 99, 29-49

Jayakumar, M., Karthikeyan, V. and Karmegam, N. (2009). Comparative studies on physico-chemical, microbiological and enzymatic activities of vermicasts of the earthworms, Eudrilus eugeniae, Lampito mauritii and Perionyx ceylanensis cultured in press mud. International Journal of Applied Agricultural Research, 4, 75-85.

Johnson, D. L. (1997). Earthworms casts reflect soil conditions. Agric. Res. 45, 19.
Lavelle, P. and A. Martin. (1992). Small-scale and large-scale effects of endogeic earthworms onsoil organic matter dynamics in soils of the humid tropics. Soil Biol. Biochem. 24, 14911498.

Logsdon, G (1994). Worldwide progress in vermicomposting. Biocycle 35, 63-65.

Madge, D. S. (1966). How leaf litters disappears. New Scientist 32, 111-115.

Madge, D. S. and Sharma, G. D. (1969). Soil Zoology. Ibadan University Press, Ibadan. p7.

Owa, S. O., Dedeke, G. A., Morafa, S. O. A. and Yeye, A. J. A. (2003). Abundance of

Earthworm in Nigerian ecological zones: Implication for sustaining fertilizer-free soil fertility. African Zoology. 38(2), 235-244.

Owa, S. O., Moreyibi, H. O., Dedeke, G. A., Olojo, F. O. and Fashunwon, O. A. (2004a). Earthworm created Micro-Environments around roots of lowland rice: Implication for growth performance. Journal of Science, Engineering andTechnology 11(1), 5261-5270.

Owa, S. O., Moreyibi, H. O., Morafa, S. O. A and Dedeke, G. A. (2004b) Contribution of Earthworms to soilTemperature and its physicochemical implication on crops. Journal of Science, Engineering and Technology 11(1), 5343-5350.

Prakash, M. Jayakumar, M. and Karmegam, N. (2008). Physico-chemical characteristics and fungal flora in the casts of the earthworm, Perionyx ceylanensis Mich. reared in Polyalthia longifolia leaf litter. Journal of Applied Sciences Research, 4, 53-57.

Sabrina1, D. T., Hanafi, M. M., Nor Azwady, A. A. and Mahmud, T. M. M. (2009). EarthwormPopulations and Cast Properties in the Soils of Oil Palm Plantations. Malaysian Journal of Soil Science 13, 29-42.

Seeley, H. W. and Denmark, P. J. (1972). Microbes in action. A Laboratory Manual of Microbiology. W.A. Freely and Co. San Francisco. pp 27-100

Segun, A. O. (1976). Two new genera of eudrilid earthworms from Nigeria. Proc. Biol. Soc.Wash. $\quad \mathbf{8 8}, 383-394$

Sims, R. W. (1971). Eudrilinea from Southern Nigeria and a Taxonomic appraisal of the family Eudrilidae (Oligochaeta). J. Zool. London. 164, 529-549

Tiunov, A.V., and Scheu, S. (2000) Microfungal communities in soil, litter and casts of Lumbricus terrestris L. (Lumbricidae): a laboratory experiment. Applied Soil Ecology. 14, 17-26. 
Torres, A.; Li, S. M.; Roussos, S. and Vert, M. (1999). Microbial degradation of a poly (lactic acid) as a model of synthetic polymer degradation mechanisms in outdoor conditions. Biopolymers. Utilizing nature's advanced materials, ACS Symposium Series 723, 218226.

Villenave, C. F., Charpentier, P., Lavelle, C., Feller, L., Brussard, B., Pashanas, I., et al. (1999).Effects of earthworms on soil organic matter and nutrient dynamics following earthworm inoculation in field experiment situations. In Lavelle, P., Brussard, L. and
Hendrix, P. (Eds.) Earthworms Management in Tropical Agroecosystems. CAB International Publishing. pp. 173-198.

Vinotha, S. P., Parthasarathi, K. and Ranganathan, L. S. (2000) Enhanced phosphatase activityin earthworm casts is more of microbial origin. Current Science, 79(9), 1158-1162.

Walkley, A. and C.A. Black. (1934). An examination of the Degtjareff method for determining soil organic matter and a proposed modification of the chromic acid titration method. Soil Sci. 37, 29-38.

Table1: Descriptive Statistics of the physicochemical parameters of the Earthworm casts

\begin{tabular}{lllllllll}
\hline Cast-types & $\begin{array}{l}\text { Mean and } \\
\text { Std. Dev. }\end{array}$ & $\boldsymbol{p H}$ & $\begin{array}{l}\text { \% moisture } \\
\text { content }\end{array}$ & $\begin{array}{l}\text { \%Organic } \\
\text { Carbon }\end{array}$ & $\begin{array}{l}\text { \%Organic } \\
\text { matter }\end{array}$ & $\begin{array}{l}\text { \% } \\
\text { Phosphate }\end{array}$ & $\begin{array}{l}\text { \% } \\
\text { Nitrate }\end{array}$ & $\begin{array}{l}\text { \% total } \\
\text { Nitrogen }\end{array}$ \\
\hline \multirow{2}{*}{ Pellet Cast } & Mean & 8.60 & 29.43 & 0.61 & 1.05 & 0.04 & 0.02 & 0.06 \\
& N & 5 & 10 & 3 & 3 & 3 & 3 & 3 \\
& Std. Dev. & 0.01 & 0.08 & 0.01 & 0.02 & 0.001 & 0.001 & 0.001 \\
\hline \multirow{2}{*}{ Turret Cast } & Mean & 8.09 & 47.10 & 0.42 & 0.72 & 0.03 & 0.01 & 0.05 \\
& N & 5 & 10 & 3 & 3 & 3 & 3 & 3 \\
& Std. Dev. & 0.01 & 0.14 & 0.01 & 0.02 & 0.001 & 0.00 & 0.001 \\
\hline \multirow{2}{*}{ Mass Cast } & Mean & 7.81 & 45.60 & 0.36 & 0.63 & 0.02 & 0.02 & 0.05 \\
& N & 5 & 10 & 3 & 3 & 3 & 3 & 3 \\
& Std. Dev. & 0.01 & 0.09 & 0.01 & 0.01 & 0.001 & .001 & 0.00 \\
\hline \multirow{2}{*}{ Total } & Mean & 8.17 & 40.71 & 0.46 & 0.79 & 0.03 & .02 & 0.06 \\
& N & 15 & 30 & 9 & 9 & 9 & 9 & 9 \\
& Std. Dev. & 0.34 & 8.14 & 0.11 & 0.19 & 0.01 & 0.002 & 0.01 \\
\hline
\end{tabular}

Table 2: Descriptive Statistics of Microbial load of Earthworm casts

\begin{tabular}{llllll}
\hline Cast-types & Mean and Std. Dev. & Total Viable Count & Coliform Count & Mould Count & Yeast Count \\
& & & & & \\
\hline Pellet Cast & Mean & $1.20 \times 10^{8}$ & $1.5 \times 10^{7}$ & $1.2 \times 10^{7}$ & $3.8 \times 10^{7}$ \\
& $\mathrm{~N}$ & 3 & 3 & 3 & 3 \\
& Std. Dev. & 0.58 & 0.58 & 0.58 & 1.00 \\
\hline \multirow{2}{*}{ Turret Cast } & Mean & $6.1 \times 10^{7}$ & $7.3 \times 10^{6}$ & $8.3 \times 10^{6}$ & $2.8 \times 10^{7}$ \\
& $\mathrm{~N}$ & 3 & 3 & 3 & 3 \\
& Std. Dev. & 1.00 & 0.58 & 0.58 & 1.00 \\
\hline Mass Cast & Mean & $4.8 \times 10^{7}$ & $1.0 \times 10^{7}$ & $1.2 \times 10^{7}$ & $1.2 \times 10^{7}$ \\
& $\mathrm{~N}$ & 3 & 3 & 3 & 3 \\
& Std. Dev. & 1.00 & 0.58 & 1.00 & 0.58 \\
\hline
\end{tabular}

Table 3: Duncan Multiple Comparison of the physicochemical parameters of the Earthworm casts.

\begin{tabular}{llll}
\multirow{2}{*}{ Parameter } & \multicolumn{3}{c}{ Cast-types } \\
\cline { 2 - 4 } & Mass Cast & Turret Cast & Pellet Cast \\
\hline pH & $7.81^{\mathrm{c}}$ & $8.09^{\mathrm{b}}$ & $8.60^{\mathrm{a}}$ \\
\% Moisture Content & $45.60^{\mathrm{b}}$ & $47.10^{\mathrm{a}}$ & $29.43^{\mathrm{c}}$ \\
\% Organic Carbon & $0.36^{\mathrm{c}}$ & $0.42^{\mathrm{b}}$ & $0.61^{\mathrm{a}}$ \\
\% Organic Matter & $0.63^{\mathrm{c}}$ & $0.72^{\mathrm{b}}$ & $1.05^{\mathrm{a}}$ \\
$\%$ Phosphate & $0.02^{\mathrm{c}}$ & $0.03^{\mathrm{b}}$ & $0.04^{\mathrm{a}}$ \\
\% Nitrate & $0.015^{\mathrm{b}}$ & $0.013^{\mathrm{c}}$ & $0.018^{\mathrm{a}}$ \\
\% Nitrogen & $0.054^{\mathrm{b}}$ & $0.048^{\mathrm{c}}$ & $0.063^{\mathrm{a}}$
\end{tabular}

\section{Means with the same superscript in a row are not significantly different}


Table 4: Duncan Multiple Comparison of the Microbial load of Earthworm casts

\begin{tabular}{llll} 
Parameter & \multicolumn{3}{c}{ Cast-types } \\
\cline { 2 - 4 } & Mass Cast & Turret Cast & Pellet Cast \\
\hline Total Viable Count & $48.00^{\mathrm{c}}$ & $61.00^{\mathrm{b}}$ & $120.33^{\mathrm{a}}$ \\
Coliform Count & $10.33^{\mathrm{b}}$ & $7.33^{\mathrm{c}}$ & $15.33^{\mathrm{a}}$ \\
Mould Count & $12.00^{\mathrm{a}}$ & $8.33^{\mathrm{b}}$ & $12.33^{\mathrm{a}}$ \\
Yeast Count & $12.33^{\mathrm{c}}$ & $28.00^{\mathrm{b}}$ & $38.00^{\mathrm{a}}$
\end{tabular}

Means with the same superscript in a row are not significantly different

Table 5: Distributions of isolates in the different cast-types

\begin{tabular}{|c|c|c|c|c|}
\hline $\mathbf{S} / \mathbf{N}$ & Isolates & Pellet Cast & Turret Cast & Mass Cast \\
\hline & Bacterial & & & \\
\hline 1. & Aerobacter aerogenes & - & + & + \\
\hline 2. & Bacillus cereus & + & + & - \\
\hline 3. & Bacillus licheniformis & + & - & + \\
\hline 4. & Citrobacter spp & + & - & - \\
\hline 5. & Escherichia coli & + & - & + \\
\hline 6. & Klebsiella aerogenes & - & - & + \\
\hline 7. & Proteus vulgaris & + & + & - \\
\hline 8. & Proteus morgani & + & - & + \\
\hline 9. & Pseudomonas fragii & + & + & - \\
\hline 10. & Pseudomonas aeruginosa & - & + & - \\
\hline 11. & Pseudomonas fluorescens & + & - & - \\
\hline 12. & Staphylococcus aureus & + & + & + \\
\hline 13. & Streptococcus faecalis & - & - & + \\
\hline 14. & $\begin{array}{l}\text { Serratia marcescens } \\
\text { Mould }\end{array}$ & + & - & + \\
\hline 15. & Aspergillus niger & + & - & + \\
\hline 16. & Aspergillus fumigatus & - & + & - \\
\hline 17. & Aspergillus terreus & - & - & + \\
\hline 18. & Fusarium compacticum & - & - & + \\
\hline 19. & Fusarium oxisporium & - & + & - \\
\hline 20. & Penicillium chrysogenum & + & - & - \\
\hline 21. & $\begin{array}{l}\text { Penicillium oxilicum } \\
\text { Yeast }\end{array}$ & - & + & - \\
\hline 22. & Candida spp & + & + & - \\
\hline 22. & Saccharomyces rosei & + & - & - \\
\hline 23. & Saccharomyces cerevisiae & - & + & + \\
\hline 24. & Saccharomyces bayanus & + & + & - \\
\hline
\end{tabular}

